\title{
Renal Resistance to Parathyroid Hormone during Phosphorus Deprivation
}

\author{
T. H. STEELE with the technical assistance of J. L. UNDERWOOD, \\ B. A. Stromberg, and C. A. LARMore \\ From the Department of Medicine, University of Wisconsin, Madison, Wisconsin, 53706
}

\begin{abstract}
A B S T RACT Because previous studies have demonstrated that renal inorganic phosphate reabsorption is enhanced in rats after dietary phosphorus deprivation, we studied the effects of parathyroid hormone (PTH) upon inorganic phosphate reabsorption in acutely thyroparathyroidectomized rats stabilized on a low phosphorus diet to determine if the phosphaturic response to PTH is impaired during phosphorus depletion. Acutely thyroparathyroidectomized phosphorus-deprived rats responded only minimally to PTH, whereas similarly prepared animals stabilized on a high phosphorus diet exhibited a large phosphaturic response. Base-line urinary cyclic AMP values and PTH-induced increases in cyclic AMP excretion were similar in both groups. In other experiments, dibutyryl cyclic AMP elicited a greatly diminished phosphaturic response in phosphorus-deprived rats, as compared to their high phosphorus counterparts. These results indicate that the renal phosphaturic responses to PTH and cyclic AMP are impaired during dietary phosphorus deprivation. The impaired phosphaturia would contribute to phosphorus conservation and to the replenishment of inorganic phosphate stores after phosphorus depletion.
\end{abstract}

\section{INTRODUCTION}

Recent studies performed in rats stabilized on a low dietary phosphorus intake have indicated that the renal capacity for inorganic phosphate $\left(\mathrm{P}_{\mathrm{i}}\right)^{1}$ reabsorption is enhanced in phosphorus depletion $(1,2)$. This acceleration of $P_{i}$ reabsorption, occurring independently of the thyroid or parathyroid glands, has profound implica-

\footnotetext{
${ }^{1}$ Abbreviations used in this paper: dbcAMP, dibutyryl
cyclic AMP; FE $\mathrm{P}_{\mathrm{i}}$, fractional inorganic phosphate excretion
value; GFR, glomerular filtration rate; $\mathrm{P}_{\mathrm{i}}$, inorganic phos-
phate; PTH, parathyroid hormone; TPTX, thyroparathyroid-
ectomized.
Received for publication 2 June 1976 and in revised form 26
August 1976 .

${ }^{1}$ Abbreviations used in this paper: dbcAMP, dibutyryl
cyclic AMP; FE $\mathrm{P}_{\mathrm{i}}$, fractional inorganic phosphate excretion
value; GFR, glomerular filtration rate; $\mathrm{P}_{\mathrm{i}}$, inorganic phos-
phate; PTH, parathyroid hormone; TPTX, thyroparathyroid-
ectomized.
Received for publication 2 June 1976 and in revised form 26
August 1976.

${ }^{1}$ Abbreviations used in this paper: dbcAMP, dibutyryl
cyclic AMP; FE $\mathrm{P}_{\mathrm{i}}$, fractional inorganic phosphate excretion
value; GFR, glomerular filtration rate; $\mathrm{P}_{\mathrm{i}}$, inorganic phos-
phate; PTH, parathyroid hormone; TPTX, thyroparathyroid-
ectomized.
Received for publication 2 June 1976 and in revised form 26
August 1976.

${ }^{1}$ Abbreviations used in this paper: dbcAMP, dibutyryl
cyclic AMP; FE $\mathrm{P}_{\mathrm{i}}$, fractional inorganic phosphate excretion
value; GFR, glomerular filtration rate; $\mathrm{P}_{\mathrm{i}}$, inorganic phos-
phate; PTH, parathyroid hormone; TPTX, thyroparathyroid-
ectomized.
Received for publication 2 June 1976 and in revised form 26
August 1976.

${ }^{1}$ Abbreviations used in this paper: dbcAMP, dibutyryl
cyclic AMP; FE $\mathrm{P}_{\mathrm{i}}$, fractional inorganic phosphate excretion
value; GFR, glomerular filtration rate; $\mathrm{P}_{\mathrm{i}}$, inorganic phos-
phate; PTH, parathyroid hormone; TPTX, thyroparathyroid-
ectomized.
Received for publication 2 June 1976 and in revised form 26
August 1976 .

${ }^{1}$ Abbreviations used in this paper: dbcAMP, dibutyryl
cyclic AMP; FE $\mathrm{P}_{\mathrm{i}}$, fractional inorganic phosphate excretion
value; GFR, glomerular filtration rate; $\mathrm{P}_{\mathrm{i}}$, inorganic phos-
phate; PTH, parathyroid hormone; TPTX, thyroparathyroid-
ectomized.
Received for publication 2 June 1976 and in revised form 26
August 1976 .

${ }^{1}$ Abbreviations used in this paper: dbcAMP, dibutyryl
cyclic AMP; FE $\mathrm{P}_{\mathrm{i}}$, fractional inorganic phosphate excretion
value; GFR, glomerular filtration rate; $\mathrm{P}_{\mathrm{i}}$, inorganic phos-
phate; PTH, parathyroid hormone; TPTX, thyroparathyroid-
ectomized.
Received for publication 2 June 1976 and in revised form 26
August 1976.
}

The Journal of Clinical Investigation Volume 58 December 1976·1461-1464

tions for phosphorus homeostasis. Such a phenomenon, by promoting renal $P_{i}$ retention, would favor the rapid replenishment of body phosphorus stores. In particular, studies performed in our laboratory utilizing rats stabilized on an extremely low dietary phosphorus intake demonstrated that the animals could maintain a phosphate-free urine in the presence of severe hyperphosphatemia (2).

Our previous experiments were performed in thyroparathyroidectomized (TPTX) rats and included the rapid infusion of phosphate (2). Because phosphate administration is known to elicit parathyroid hormone (PTH) secretion (3), it seems likely that the serum PTH concentration would have increased if those experiments had been performed in animals with intact functioning parathyroids. The PTH released could elicit a phosphaturic response which would diminish or even nullify the correction of phosphorus depletion. In the studies reported here, we have examined the phosphaturic response to the administration of PTH in rats stabilized on a low dietary intake of phosphorus and compared the results with animals receiving a high phosphorus diet.

\section{METHODS}

Adult male Sprague-Dawley rats weighing 250-350 g were stabilized on one of two dietary regimens for 25-35 days before clearance experiments. The low phosphorus diet (ICN Pharmaceuticals Inc., Life Sciences Group, Cleveland, Ohio) contained $0.07 \%$ phosphorus and $1.0 \%$ calcium. The high phosphorus diet contained $1.0 \%$ phosphorus and $1.6 \%$ calcium. Food, but not water, was withheld for $16 \mathrm{~h}$ before the experiments which all commenced at the same hour of the morning.

Each rat was anesthetized with Inactin (Promonta, Hamburg, W. Germany) $80-100 \mathrm{mg} / \mathrm{kg}$ i.p. and placed on an electrically heated platform where body temperature could be maintained at $37-38^{\circ} \mathrm{C}$ utilizing a rectal thermistor probe. After a tracheostomy, thyroparathyroidectomy was performed surgically. In addition, the urinary bladder and one external carotid artery and jugular vein were cannulated with polyethylene tubing. The mean arterial pressure was monitored utilizing a transducer connected to the arterial cannula. 
TABLE I

Response to PTH in Acutely TPTX Rats

\begin{tabular}{|c|c|c|c|c|c|c|c|c|c|c|c|c|}
\hline & \multicolumn{2}{|c|}{$\mathrm{Pl}_{\mathrm{asma}} \mathrm{P}_{\mathrm{i}}$} & \multicolumn{2}{|c|}{ GFR } & \multicolumn{2}{|c|}{$P_{i}$ excretion } & \multicolumn{2}{|c|}{$\mathrm{FE}_{\mathrm{P}} \times 100$} & \multicolumn{2}{|c|}{ Sodium excretion } & \multicolumn{2}{|c|}{$\begin{array}{l}\text { Cyclic AMP } \\
\text { excretion }\end{array}$} \\
\hline & Control & PTH & Control & РТн & Control & PTH & Control & РТн & Control & PTH & Control & РТн \\
\hline & \multicolumn{2}{|c|}{$\mathrm{mg} / 100 \mathrm{ml}$} & \multicolumn{2}{|c|}{$\mathrm{ml} / \mathrm{min} / 100 \mathrm{~g}$} & \multicolumn{2}{|c|}{$\mu \mathrm{g} / \mathrm{min} / 100 \mathrm{~g}$} & \multicolumn{2}{|c|}{$\%$} & \multicolumn{2}{|c|}{$\mu e(\mathrm{~g} / \mathrm{min} / 100 \mathrm{~g}$} & \multicolumn{2}{|c|}{$\mathrm{pmol} / \mathrm{min} / 100 \mathrm{~g}$} \\
\hline \multicolumn{13}{|c|}{$\begin{array}{l}\text { High phosphorus (1\% P) } \\
\quad \text { diet }(n=7)\end{array}$} \\
\hline $\begin{array}{l}\text { Mean } \\
( \pm \text { SEM })\end{array}$ & $\begin{array}{r}7.4 \\
( \pm 0.2)\end{array}$ & $\begin{array}{r}8.5^{*} \\
( \pm 0.2)\end{array}$ & $\begin{array}{r}0.99 \\
( \pm 0.08)\end{array}$ & $\begin{array}{r}0.93 \\
( \pm 0.03)\end{array}$ & $\begin{array}{r}0.12 \\
( \pm 0.0 .3)\end{array}$ & $\begin{array}{r}12.4 t \\
( \pm 1.6)\end{array}$ & $\begin{array}{r}0.18 \\
\pm 0.06)\end{array}$ & $\begin{array}{r}1.5 .9 ! \\
( \pm 2.2)\end{array}$ & $\begin{array}{c}1.3 \\
( \pm 0.5)\end{array}$ & $\begin{array}{r}2.5 \S \\
( \pm 0.2)\end{array}$ & $\begin{array}{c}26.0 \\
( \pm 2.4)\end{array}$ & $\begin{array}{r}48.41 \\
( \pm 2.8)\end{array}$ \\
\hline \multicolumn{13}{|c|}{$\begin{array}{l}\text { Low phosphorus }(0.07 \% \mathrm{P}) \\
\text { diet }(n=10)\end{array}$} \\
\hline $\begin{array}{l}\text { Mean } \\
( \pm \text { SEM })\end{array}$ & $\begin{array}{r}6.4 \\
( \pm 0.3)\end{array}$ & $\begin{array}{r}7.41 \\
( \pm 0.3)\end{array}$ & $\begin{array}{c}0.77 \\
( \pm 0.03)\end{array}$ & $\begin{array}{r}0.92 \\
( \pm 0.05)\end{array}$ & $\begin{array}{r}0.066 \\
( \pm 0.008)\end{array}$ & $\begin{array}{r}0.11 \ddagger \\
( \pm 0.01)\end{array}$ & $\begin{array}{r}0.16 \\
( \pm 0.04)\end{array}$ & $\begin{array}{r}0.18 \\
( \pm 0.03)\end{array}$ & $\begin{array}{r}0.86 \\
( \pm 0.36)\end{array}$ & $\begin{array}{r}1.6 \rrbracket \\
( \pm 0.4)\end{array}$ & $\begin{array}{c}28.2 \\
( \pm 3.5)\end{array}$ & $\begin{array}{r}57.9^{*} \\
( \pm 6.8)\end{array}$ \\
\hline$P$ & $<0.05$ & $<0.02$ & $<0.02$ & $\mathrm{xS}$ & $<0.05$ & $<0.001$ & $\mathrm{xS}$ & $<0.001$ & $\mathrm{NS}$ & NS & NS & $\mathrm{NS}$ \\
\hline
\end{tabular}

Symbols indicate significant paired changes from control, within the same experimental group, as follows: ${ }^{*} P<0.005 ; \square<0.001 ; \$ P<0.02$; $P<0.05$; otherwise, $P>0.05$. $P$ values in the table indicate unpaired comparisons between different groups during similar experimental phases. NS, $P>0.05$.

Each animal received $0.15 \mathrm{M} \mathrm{NaCl}, 10 \mathrm{ml} / \mathrm{kg}$, to replace surgical losses, and a priming dose of inulin $(1 \mathrm{ml} / \mathrm{kg}$ of an $8 \%$ solution). This was followed by a sustaining inulin infusion of $320 \mathrm{mg} / \mathrm{kg}$ per h, which was delivered in $0.15 \mathrm{M}$ $\mathrm{NaCl}$ infused at $30 \mathrm{ml} / \mathrm{kg}$ per $\mathrm{h}$ throughout the entire experiment. A minimum of $1 \mathrm{~h}$ was allowed for recovery from the surgical procedures before commencing the clearance periods. Then specimens for two 30 -min control clearance periods were obtained. Sufficient arterial blood to obtain $80 \mu \mathrm{l}$ of plasma was withdrawn at the midpoint of each clearance period. Urine volumes were measured by differential weighing in tared containers.

After completion of the two control periods, each animal received either synthetic bovine PTH (1-34) tetratriacontapeptide (Beckman Instruments, Inc., Fullerton, Calif.) or dibutyryl cyclic AMP (Sigma Chemical Co., St. Louis, Mo.). The synthetic PTH peptide had a specific activity of approximately $3.9 \mathrm{U} / \mu \mathrm{g}$. It was administered at an initial dosage of $13 \mathrm{U} / \mathrm{kg}$ which was followed by constant infusion of $13 \mathrm{U} / \mathrm{kg}$ per $\mathrm{h}$ in the inulin-saline solution for the remainder of the experiment. The dibutyryl cyclic AMP (dbcAMP) was administered at an initial dosage of $10 \mathrm{mg} / \mathrm{kg}$ followed by the constant infusion of $10 \mathrm{mg} / \mathrm{kg}$ per $\mathrm{h}$ in the inulin-saline solution for the remainder of the experiment. After a 30-min equilibration interval during either PTH or dbcAMP infusion, specimens for three 20-min experimental clearance periods were obtained.

Analytical methods for most solutes have been reported previously (2). Urinary cyclic AMP was measured by the radioimmunoassay method of Steiner et al. (4) utilizing commercially available reagent (Schwarz Mann Div., Becton, Dickinson \& Co., N. Y.). Cyclic AMP measurements were made in triplicate on each urine specimen. The clearance of inulin was utilized as a measurement of glomerular filtration rate (GFR). GFR and the absolute $P_{i}$ and sodium excretions were expressed per 100 grams of body weight. For each experiment, the two control periods and the three experimental periods were averaged separately. The means and standard errors of these averages were obtained for Tables I and II. In addition, the means of all the corresponding individual clearance periods were obtained for the data presented in Fig. 1. Statistical comparisons utilized paired or unpaired Student's $t$ tests, as appropriate (2).

\section{RESULTS}

PTH infusion. After the infusion of PTH, GFR remained stable in the high dietary phosphorus rats, and increased slightly in the low phosphorus group (Table I). Sodium excretion increased to a similar degree in both groups. Plasma $P_{i}$ was greater, by $1 \mathrm{mg} / 100 \mathrm{ml}$, in the animals stabilized on the high phosphorus regimen. Control $\mathrm{P}_{\mathrm{i}}$ excretion rates in both groups of acutely TPTX rats were very low; fractional $\mathrm{P}_{\mathrm{i}}$ excretion values $\left(\mathrm{FE}_{\mathrm{P}_{\mathrm{i}}}\right.$ ) were similar in both. Plasma calcium averaged $10.6 \pm 0.4 \mathrm{mg} / 100 \mathrm{ml}$ in the high phosphorus group and $11.6 \pm 0.4 \mathrm{mg} / 100 \mathrm{ml}$ in the low phosphorus group (mean \pm SEM) and was not correlated with $\mathrm{P}_{\mathrm{i}}$ excretion.

After PTH infusion, $\mathrm{P}_{\mathrm{i}}$ excretion in the high phosphorus group increased about 100 -fold. $P_{i}$ excretion increased to a trivial but statistically significant degree in the low phosphorus rats after PTH (Table I). $P_{i}$ excretion in the low phosphorus group after PTH was very similar to the control $P_{i}$ excretion in the high phosphorus group before receiving PTH (Table I). $\mathrm{FE}_{\mathbf{P}_{\mathbf{i}}}$ increased substantially in the high phosphorus animals, but remained unchanged after PTH in the low phosphorus rats (Table I). Furthermore, despite similar control values, there was no overlap in phosphaturic responses between the high and low phosphorus groups.

Cyclic AMP excretion rates during control periods were very similar in both groups (Table I). After receiving PTH, mean cyclic AMP excretion approximately doubled in each group. PTH elicited an increase in cyclic AMP excretion in every rat, except for one phosphorus-deprived animal. Because of the slightly diminished GFR values in the low phosphorus rats, cyclic AMP excretion per unit of GFR was slightly 
greater in that group (Fig. 1). During PTH infusion in the high phosphorus animals, $\mathrm{FE}_{\mathrm{P}_{\mathbf{i}}}$ climbed in a stepwise manner, with the values during the second and third experimental clearance periods significantly exceeding those during the first $(P<0.01)$. However, the response of $\mathrm{FE}_{\mathrm{P}_{\mathbf{i}}}$ in the low phosphorus group was essentially flat (Fig. 1). Cyclic AMP excretion was relatively stable during the three experimental clearance periods in both the high and low dietary phosphorus groups (Fig. 1).

dbcAMP infusion. In the high and low phosphorus animals receiving dbcAMP, GFR values remained stable (Table II). Sodium excretion increased substantially after dbcAMP in both groups. Again control plasma $P_{i}$ values were significantly greater in the high phosphorus group, whereas $F_{P_{i}}$ and absolute $P_{i}$ excretion values were similar (Table II).

During dbcAMP infusion, absolute $P_{i}$ excretion and $\mathrm{FE}_{\mathrm{P}_{\mathrm{i}}}$ increased more than 50-fold over control values in the rats stabilized on the high phosphorus diet (Table II). In contrast, the low phosphorus rats exhibited a significantly blunted phosphaturic response to dbcAMP (Table II). Although dbcAMP did elicit a mild degree of phosphaturia in most of the phosphorus-deprived animals, the responses again did not overlap those in the high phosphorus group.

\section{DISCUSSION}

These data indicate that the phosphaturic response to PTH is greatly ameliorated in the TPTX phosphorusdeprived rat. However, the diminished phosphaturic response was not accompanied by any diminution in the response of urinary cyclic AMP to PTH. Although the urinary cyclic AMP may not accurately reflect the extent of PTH-induced renal cyclic AMP synthesis,
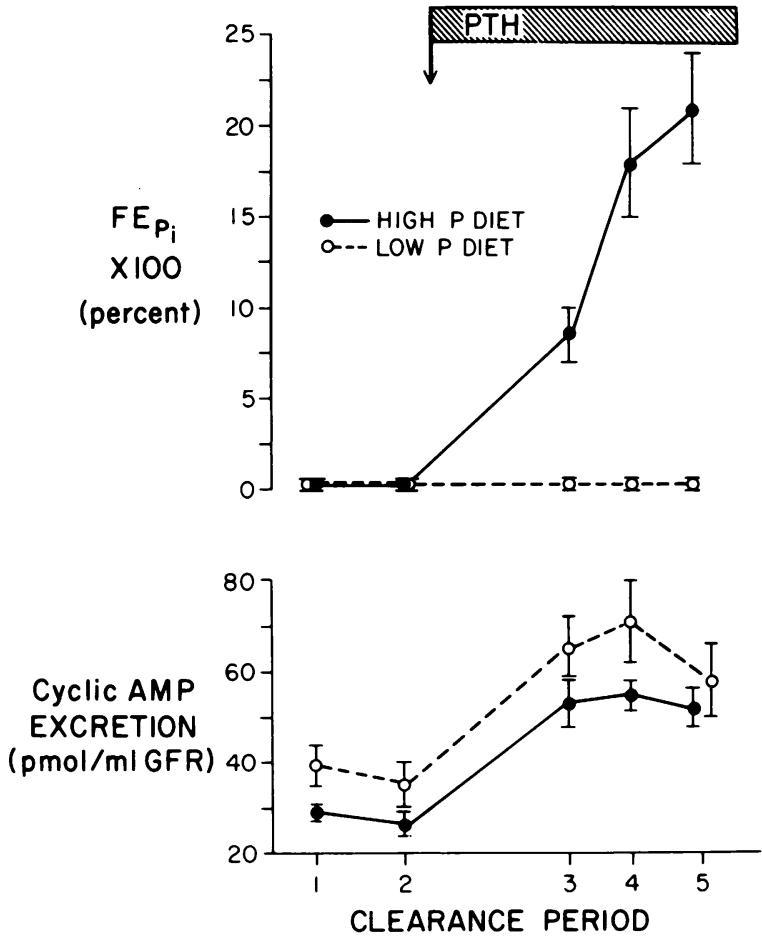

FIGURE 1 Development of phosphaturic and urinary cyclic AMP responses to PTH. Means and SEM are depicted for individual clearance periods. $\mathrm{FE}_{\mathrm{P}_{\mathbf{i}}}$ increased in stepwise fashion during PTH administration in the high phosphorus group. Urinary cyclic AMP tended to assume a plateau value during PTH infusion in both groups.

the diminished phosphaturic response to dbcAMP in the phosphorus-deprived rats is consistent with the possibility that phosphorus depletion may decrease the response to endogenously produced cyclic AMP within the renal cortex. Although dbcAMP did produce a modest phosphaturic response in the low phosphorus

TABLE II

Response to dbcAMP in Acutely TPTX Rats

\begin{tabular}{|c|c|c|c|c|c|c|c|c|c|c|}
\hline & \multicolumn{2}{|c|}{ Plasma $P_{i}$} & \multicolumn{2}{|c|}{ GFR } & \multicolumn{2}{|c|}{$P_{i}$ excretion } & \multicolumn{2}{|c|}{$\mathrm{FE}_{\mathrm{Pi}} \times 100$} & \multicolumn{2}{|c|}{ Sodium excretion } \\
\hline & Control & dbc:AMP & Control & dbcAMP & Control & dbcAMP & Control & dbcAMP & Control & dbcAMP \\
\hline & \multicolumn{2}{|c|}{$m g / 100 \mathrm{ml}$} & \multicolumn{2}{|c|}{$\mathrm{ml} / \mathrm{min} / 100 \mathrm{~g}$} & \multicolumn{2}{|c|}{$\mu \mathrm{g} / \mathrm{min} / 100 \mathrm{~g}$} & \multicolumn{2}{|c|}{$\%$} & \multicolumn{2}{|c|}{$\mu e q / \min / 100 \mathrm{~g}$} \\
\hline $\begin{array}{r}\text { High phosph } \\
\quad \operatorname{diet}(n=1\end{array}$ & & & & & & & & & & \\
\hline $\begin{array}{l}\text { Mean } \\
( \pm \text { SEMI })\end{array}$ & $\begin{array}{c}7.9 \\
( \pm 0.2)\end{array}$ & $\begin{array}{c}7.7 \\
( \pm 0.3)\end{array}$ & $\begin{array}{c}1.03 \\
( \pm 0.04)\end{array}$ & $\begin{array}{c}0.99 \\
( \pm 0.05)\end{array}$ & $\begin{array}{c}0.35 \\
( \pm 0.12)\end{array}$ & $\begin{array}{r}19.8^{*} \\
( \pm 1.6)\end{array}$ & $\begin{array}{c}0.42 \\
( \pm 0.16)\end{array}$ & $\begin{array}{r}26.9^{*} \\
( \pm 2.4)\end{array}$ & $\begin{array}{c}0.97 \\
( \pm 0.19)\end{array}$ & $\begin{array}{r}3.17^{*} \\
( \pm 0.50)\end{array}$ \\
\hline \multicolumn{11}{|c|}{$\begin{array}{l}\text { Low phosphorus }(0.07 \% \mathrm{P}) \\
\operatorname{diet}(n=8)\end{array}$} \\
\hline $\begin{array}{l}\text { Mean } \\
( \pm \text { SE.M })\end{array}$ & $\begin{array}{c}7.2 \\
( \pm 0.2)\end{array}$ & $\begin{array}{c}7.3 \\
( \pm 0.2)\end{array}$ & $\begin{array}{r}0.99 \\
( \pm 0.10)\end{array}$ & $\begin{array}{c}0.92 \\
( \pm 0.07)\end{array}$ & $\begin{array}{c}0.077 \\
( \pm 0.015)\end{array}$ & $\begin{array}{r}0.69 ! \\
( \pm 0.49)\end{array}$ & $\begin{array}{c}0.11 \\
( \pm 0.02)\end{array}$ & $\begin{array}{r}1.21 \rrbracket \\
( \pm 0.91)\end{array}$ & $\begin{array}{c}1.3 \\
( \pm 0.4)\end{array}$ & $\begin{array}{r}4.4 \S \\
( \pm 0.9)\end{array}$ \\
\hline$P$ & $<0.05$ & NS & NS & NS & NS & $<0.001$ & NS & $<0.001$ & NS & NS \\
\hline
\end{tabular}

Symbols indicate significant paired changes from control, within the same experimental group, as follows: ${ }^{*} P<0.001 ; \downarrow P<0.05 ; \S P<0.02$; otherwise, $P>0.05$.

$P$ values in the table indicate unpaired comparisons between different groups during similar experimental phases. NS, $P>0.05$. 
rats, the magnitude of the response clearly was far less than that in the animals stabilized on the high phosphorus diet.

In the present experiments, the low control $\mathrm{FE}_{\mathrm{P}_{\mathrm{i}}}$ values in the high phosphorus groups suggest that the residual biologic action of endogenous PTH probably was minimal within $1 \mathrm{~h}$ after TPTX. In addition, previous half-time measurements for PTH disappearance in the rat of approximately $20 \mathrm{~min}(5)$ are consistent with this view.

In the contrast to a previous study from this laboratory (2), the rats stabilized on the low phosphorus regimen were not hypophosphatemic. Three factors probably account for this. First, older animals were utilized instead of the weanlings of the previous study (2). Second, again in contrast to the previous study, the rats were fasted overnight before the experiments. Unpublished observations have indicated that the plasma $P_{i}$ increases by an average of $1.3 \mathrm{mg} / 100 \mathrm{ml}$ $(P<0.05)$ after a 16 -h fast in adult rats stabilized on the same low phosphorus diet. In contrast, plasma $P_{i}$ decreased by $0.7 \mathrm{mg} / 100 \mathrm{ml}$ when rats on the high phosphorus regimen were fasted $(P<0.05)$. Finally, the dietary phosphorus content was only $0.02 \%$ in the previous study (2), compared to $0.07 \%$ in the present experiments.

One report has included data on $\mathrm{P}_{\mathrm{i}}$ and cyclic AMP excretion after the administration of glucose in the phosphorus-depleted dog (6). Under those experimental conditions, both the urinary $P_{i}$ and cyclic AMP excretions appeared relatively normal. Conceivably, glucose could have diminished $\mathrm{P}_{\mathrm{i}}$ reabsorption during phosphorus depletion under those circumstances. Preliminary reports from our laboratory have indicated that volume expansion with $\mathrm{NaCl}$ or $\mathrm{NaHCO}_{3}$ can partially inhibit the avid $\mathrm{P}_{\mathrm{i}}$ reabsorption characteristic of phosphorus-depleted rats $(7,8)$.

The significance of these observations rests in the interpretation that the kidney possesses a special facility for the correction of phosphorus depletion. We have demonstrated previously that the TPTX phosphorus-depleted rat can maintain a phosphate-free urine despite the presence of severe hyperphosphatemia, with $\mathrm{FE}_{\mathrm{p}_{\mathrm{i}}}$ values less than $1 \%$, due to enhanced $P_{i}$ reabsorption (2). Tröhler et al. (1) also have shown a salutory effect of phosphorus deprivation on $\mathrm{P}_{\mathrm{i}}$ reabsorption, but their rats maintained $\mathrm{FE}_{\mathrm{P}_{\mathrm{i}}}$ values in excess of $60 \%$ during hyperphosphatemia. Because of the stimulus to PTH secretion accompanying large $P_{i}$ loads (3), an inhibitory action of PTH upon $P_{i}$ reabsorption might be expected to take precedence over $\mathrm{P}_{\mathrm{i}}$ conservation. The present observations indicate that, even in the presence of large amounts of PTH, the repletion of phosphorus from the depleted state could proceed unabated as a consequence of a diminished action of PTH upon renal $\mathrm{P}_{\mathrm{i}}$ transport.

\section{ACKNOWLEDGMENT}

This work was supported by a grant from The Kroc Foundation.

\section{REFERENCES}

1. Tröhler, U., J-P. Bonjour, and H. Fleisch. 1976. Inorganic phosphate homeostasis. Renal adaptation to the dietary intake in intact and thyroparathyroidectomized rats. J. Clin. Invest. 57: 264-273.

2. Steele, T. H., and H. F. DeLuca. 1976. Influence of dietary phosphorus on renal phosphate reabsorption in the parathyroidectomized rat.J. Clin. Invest. 57: 867-874.

3. Reiss, E., J. M. Canterbury, M. A. Bercovitz, and E. L. Kaplan. 1970. The role of phosphate in the secretion of parathyroid hormone in man. J. Clin. Invest. 49: 21462149 .

4. Steiner, A. L., D. M. Kipnis, R. Utiger, and C. Parker. 1969. Radioimmunoassay for the measurement of adenosine 3',5'-cyclic phosphate. Proc. Natl. Acad. U.S.A. 64: $367-373$.

5. Melick, R. A., G. D. Aurbach, and J. T. Potts, Jr. 1965. Distribution and half-life of ${ }^{131}$ I-labeled parathyroid hormone in the rat. Endocrinology. 77: 198-202.

6. Harter, H. R., A. Mercado, W. E. Rutherford, H. Rodriguez, E. Slatopolsky, and S. Klahr. 1974. Effects of phosphate depletion and parathyroid hormone on renal glucose reabsorption. Am. J. Physiol. 227: 1422-1427.

7. Steele, T. H., C. A. Larmore, and J. L. Underwood. 1976. Effect of volume expansion and parathyroid (PTH) function on phosphate $(\mathrm{P})$ reabsorption during $\mathrm{P}$ depletion. Clin. Res. 24: 412A. (Abstr.)

8. Steele, T. H., J. L. Underwood, and C. A. Larmore. 1976. Relationship of bicarbonate (B) to the reabsorption of phosphate (P) during hyperphosphatemia. Clin. Res. 24: 412A. (Abstr.) 